\title{
DAKWAH DALAM ARUS GLOBALISASI MEDIA: PELUANG DAN TANTANGAN
}

\author{
Oleh: Muhammad Haramain \\ Sekolah Tinggi Agama Islam Negeri (STAIN) Parepare \\ Email: haramain84@gmail.com
}

\begin{abstract}
The dynamics of Islamic media have a fundamental problem in the position of global communications controlled by Western hegemony so strong and become the main players. Islam does not have a significant position. Countries that have a majority Muslim people much depend on the information provided by the West, especially the United States. In terms of communication media, generally third world countries, including Islam only as consumers whose utilization has not been maximally felt by all citizens. Moreover, being a producer in creating communication media, it seems too far to be expected.

The implications arising from such an Islamic position, in global communication, of course, Islam does not yet have the power to play a significant role. The presence of Islam in global communications is only limited to the discourse that has great potential to rise. In order to further enhance its role in global communications, Muslims should make systematic efforts to catch up. Efforts should be made are: First, make the teachings of Islam as a source of vitality of civilization; Second, establishing harmonious cooperation between Islam and the West, especially the media; Third, improve the ability of Muslims in the mastery of science and technology, especially communications and build world news agencies; Fourth, Islamic institutions can play their part in the global arena; Fifth, cooperation between Islamic countries needs to be improved.
\end{abstract}

Keywords: Media Dakwah, information technology, globalization 


\section{Pendahuluan}

Pada era globalisasi ini kita menyaksikan terjadinya persaingan yang tidak seimbangantara apa yang dikelompokkan sebagai Barat dan Timur, atau Utara dan Selatan. Dari segi ilmu pengetahuan, teknologi dan pandangan hidup, dunia dibagi menjadi Barat dan Timur. Barat untuk negara-negara yang maju ilmu pengetahuan dan teknologinya serta punya pandangan hidup rasional dan sekuler; Timur sebaliknya. Sedangkan dari segi ekonomi, dunia dibagi menjadi Utara dan Selatan. Utara untuk negara-negara yang maju ekonominya, sedangkan Selatan untuk negara-negara berkembang dan terbelakang. Letak geografis sama sekali tidak menjadi pertimbangan. Maroko yang terletak di Barat dimasukkan dalam kelompok Timur, sementara Jepang yang terletak diTimur dmasukkan dalam kelornpok Utara.Australia yang terletak di Selatan dimasukkan kelompok Utara. Seluruh negara-negara yang tergabung dalam Organisasi Konferensi Islam (OKI), termasuk Indonesia, masuk dalam kelompok negara-negara Timur dan Selatan.

Dengan kemajuan teknologi komunikasi yang demikian hebat, masing masing anggota masyarakat dunia dapat bekerja sama,bersaing dan saling mempengaruhi dengan bebas. Sekat-sekat geografis dan jarak yang berjauhan tidak lagi menjadi hambatan. Dari segi ekonomi, setelah pasar bebas ASEAN (AFTA) kita juga menyaksikan pasar bebas Asia Pasifik (APEC) dan terakhir pasar bebas Dunia (WTO). Tetapi karena kekuatan modal, sumber daya manusia, manajemen, teknologi dan industri dikuasai oleh negaranegara Utara. Akibatnya persaingan yang terjadi persaingan yang tidak seimbang. Khusus kepentingan pendidikan dan bukan untuk kepentingan komersial, dengan tetap mencantumkan atribut penulis dan keterangan dokumen ini secara lengkap.

Indonesia, jangankan untuk tingkat dunia,tingkat ASEAN pun kita kesulitan untuk memenangi persaingan. Begitu juga dari segi budaya - dan ini yang lebih berbahaya lagi-bermacammacam ideologi, paham dan gaya hidup akan saling mempengaruhi dengan cepat, mengubah dengan cepat pula tatanan masyarakat. Sekali lagi, walaupun secara teoritis semua anggota masyarakat dunia saling mempengaruhi, karena kekuatan yang tidak seimbang, yang akan menguasai dan memaksakan pandangannya adalah negara-negara Barat. Sebagai 
ilustrasi, kalau kita pergi ke Eropa atau Amerika, sudah dapat dipastikan kita tidak akan dapat menonton acara-acara televisi dari Indonesia. Tetapi sebaliknya jika kita buka stasiun TV Indonesia mana pun, dengan mudah akan kita dapatkan acara-acara produk Barat. Khusus untuk Indonesia, tidak hanya film-film Hollywood yang mudah kita tonton, bahkan film-film Bollywood dan Amerika Latin pun tidak pernah absen muncul di TV-TV kita! Sadar atau tidak, pengaruhnya sangat besar dalam pertarungan budaya. Pandangan dan gaya hidup yang bertentangan dengan ajaran Islam akan mempengaruhi anak-anak kita, bahkan mungkin juga orang dewasa.

Sebagai akibat dan pertarungan budaya yang tidak seimbang di atas, maka kita dapat menyaksikan tcrjadinya perubahan-perubahan alam pikiran yang cenderung pragmatis, materialis, dan hedonis, menumbuhkan budaya indrawi (kebudayaan duniawi yang sekuler) dalam kehidupan modern abadke-20 yang disertai dengan gaya hidup modern memasuki era baru abad ke-21 atau abad kc15 Hijriah sekarang ini. Penetrasi budaya dan multikulturalisme yang dibawa oleh globalisasi akan makin nyata dalam kehidupan bangsa.

Setiap negara atau bangsa akan masuk dalam arus globalisasi. Yang tidak dapat berenang akan tenggalam dalam pusaran arus yang sangat deras tersebut. Apalagi negara-negara Barat atau Utara menghendaki globalisasi tentu saja bukan tanpa kepentingan nasional masing-masing, baik ekonomi, budaya maupun ideologi atau paling kurang pandangan hidup. Dunia Islam yang semuanya tanpa kecuali masuk Timur atau Selatan tentu saja tidak akan mampu menahan laju globalisasi itu, apalagi menghentikannya. Karena itu, globalisasi sudah merupakan realitas sejarah yang tidak dapat ditolak. Globalisasi adalah konsekuensi logis dari kemajuan teknologi komunikasi.

\section{Dakwah Islam: Nilai-Nilai dan Tradisi Berkomunikasi}

Kajian tentang nilai-nilai dan tradisi yang ada pada Islam tentunya perlu untuk membongkar dan menganalisis sumber ajaran Islam yang pokok, yakni alQur'an dan Hadis. Di dalam al-Qur'an dan hadis Nabi terdapat banyak keterangan berkenaan dengan adanya komunikasi. Dalam hal ini komunikasi dipahami 
sebagai sebuah proses penciptaan makna antara dua orang atau lebih lewat penggunaan simbol-simbol atau tanda-tanda. ${ }^{1}$

Oleh karenanya, dialog antara Jibril dengan Muhammad ketika pertama kali turun wahyu di Gua Hira dapat dikategorikan sebagai proses komunikasi. Di dalam dialog tersebut, Nabi yang awalnya tidak memahami apa yang ingin disampaikan oleh malaikat Jibril, pada akhirnya memahami dan mengikuti apa yang disampaikan oleh Jibril yang kemudian dikenal dengan wahyu pertama surat al-Alaq ayat 1-5.

Begitu juga ketika Nabi menyampaikan (menceritakan) peristiwa yang dialaminya kepada Istrinya dan seorang pendeta dapat dikatakan sebagai proses komunikasi. Betapa tidak, cerita yang dikisahkan oleh Nabi kepada isteri dan pendeta begitu jelas dan mendapat respons yang positif dari kedua orang tersebut. Hal ini berarti ada kesesuaian makna yang bisa ditangkap dari komunikator (Nabi) kepada komunikan (Khadijah dan Pendeta).

Tradisi komunikasi semakin sistematis terjadi ketika Nabi mulai mengajak umatnya untuk masuk Islam atau yang dikenal dengan istilah tabligh. Menurut Ibnu Khaldun seorang Filosof dari Andalusia bahwa istilah tabligh merupakan sebuah teori komunikasi dan etika. ${ }^{2}$ Dikatakan demikian mengingat di dalam ajaran Islam tabligh dalam operasionalisasinya tidak bisa dilepaskan dengan etika. Tanpa etika, tabligh akan berjalan secara sewenang-wenang. Oleh karena itu, ada beberapa prinsip yang mesti dipegang ketika hendak mengembangkan tabligh.

Pertama, tabligh hendaknya memegang prinsip tawhid sebagai prinsip fundamental dalam setiap aspek kehidupan. Dengan berpegang kepada prinsip ini, maka tabligh lebih diarahkan kepada usaha untuk menghancurkan atau membebaskan segala macam mitos yang menerpa individu maupun masyarakat. Di dalam era global seperti sekarang ini, mitos dapat berbentuk kekuatan (power), kekuasaan, modernisasi, media dan segala hal yang dapat menguasai individu atau

\footnotetext{
${ }^{1}$ Deddy Mulyana, Nuansa-Nuansa Komunikasi Meneropong Politik dan Budaya Komunikasi Masyarakat Kontemporer (Bandung: Remaja Rosdakarya, 1999), h. 49

${ }^{2}$ Hamid Mowlana, Global Communication In Transition The End of Diversity? (California: Sage Publications, Inc, 1996), h. 116
} 
masyarakat yang dapat mengalahkan manusia untuk tunduk kepada kekuasaan Tuhan. Prinsip ini sejalan dengan firman Allah "Dan Kami tidak mengutus seorang rasul pun sebelum kamu, melainkan Kami wahyukan kepadanya, bahwasanya tidak ada Tuhan melainkan Aku, maka sembahlah olehmu sekalian akan Aku" (Q.S. Al-Anbiya: 25).

Kedua, prinsip amar ma'ruf nahy munkar (commanding to the right and prohibiting from the wrong). Prinsip ini merupakan prinsip tanggung-jawab setiap individu maupun institusi untuk mengajak orang lain atau institusi lain dalam menegakkan kepemimpinan dan cita-cita Islam. Dalam hal ini, institusi tidak hanya terbatas pada institusi dakwah, melainkan juga institusi-institusi seperti pers, radio, film dan sebagainya. Dalam menjalankan tanggung-jawab, al-Qur'an memberikan petunjuk dengan cara bijaksana (hikmah), nasehat yang baik dan dengan cara mujadalah yang ihsan (Q.S. al-Nahl: 125)

Ketiga, prinsip ummah. Prinsip ini terutama berkaitan dengan kehidupan politik individu dan masyarakat Islam. Konsep ummah dalam Islam melebihi dari batas-batas negara dan batas-batas politik. Dengan konsep ini, Islam tidak memisahkan antara individu satu dengan individu lain sebagai anggota masyarakat. Ras, etnis, kesukuan dan nasionalisme tidak diakui oleh Islam. Islam mengakui adanya kebangsaan, perbedaan budaya, dan faktor geografis, tetapi Islam menolak adanya dominasi yang berdasarkan kepada kebangsaan. Oleh karenanya, tabligh dalam kerangka politik, spiritual dan etika harus memainkan peran yang dapat memelihara kesatuan komunitas Islam. Kemudian, tabligh pada level individu dan sosial berperan untuk menjaga hubungan yang harmonis antara Tuhan, individu dan masyarakat.

Keempat, prinsip taqwa. Prinsip ini menjadi landasan gerak setiap individu muslim di dalam menjalankan tabligh. Mengingat taqwa di dalam Islam menjadi standar kualitas seseorang dihadapan Allah, dan segala aktivitas yang kita lakukan semuanya mengharap kepada keridlaan-Nya. Oleh karena itu, taqwa hendaknya dijadikan landasan utama individu muslim dalam melakukan aktivitasnya.

Berdasarkan uraian di atas jelaslah bahwa tabligh merupakan elemen penting di dalam membangun individu dan masyarakat. Tak heran apabila Ibnu 
Khaldun mengatakan bahwa tabligh dan Ashabiah merupakan dua faktor penting untuk kebangkitan dan kekuatan sebuah negara atau komunitas. ${ }^{3}$ Lebih jauh Ibnu Khaldun memahami tabligh sebagai institusi sosial yang tumbuh berdasarkan kebutuhan dari masyarakat. Tabligh merupakan sebuah forum umum yang berguna untuk bertukar pikiran antara orang-orang yang berbeda ras, bahasa dan sejarah. Oleh karenanya, sistem negara, pemerintahan dan politik akan memiliki kekuatan dan otoritas yang tinggi manakala sistem tersebut bersumber dari persaudaraan (ashabiah) dan tabligh yang dibawa oleh para orator (komunikator). ${ }^{4}$

Adanya tradisi tabligh yang berkembang di kalangan Islam—seperti yang diakui oleh Ibnu Khaldun-memberikan indikasi yang jelas bahwa tradisi komunikasi yang dominan dalam Islam adalah tradisi komunikasi lisan (oral communication). Hal ini pun diperkuat dengan beberapa keterangan ayat alQur'an yang membicarakan tentang tradisi lisan yang banyak dijadikan dalil oleh para ilmuwan Muslim. Al-Qur'an memerintahkan agar seorang da'i (komunikator) mengajak kepada mad'u (komunikan) dengan perkataan yang ma'ruf seperti tercantum dalam Q.S. an-Nisa ayat 5, perkataan yang mulia seperti tercantum dalam Q.S. al-Isra ayat 23, perkataan yang lemah-lembut (qaulan layyina) seperti tertera pada Q.S. Thaha ayat 44, dan perkataan yang berbekas pada jiwa (qaulan laligha) seperti yang terdapat dalam Q.S. an-Nisa ayat 63.

\section{Urgensi Media Dakwah dalam Arus Globalisasi Media}

Pada zaman Rasulullah berkembang tradisi tulis-menulis. Terbukti ketika Rasulullah menerima wahyu langsung beliau memerintahkan kepada para Sahabat yang memiliki kemampuan menulis untuk menulis wahyu yang diterima Rasulullah. Padahal saat itu secara teknis sulit untuk melakukan tulis-menulis disebabkan belum tersedianya sarana seperti kertas dan alat tulis pena, disamping budaya yang kurang mendukung. Tetapi, para Sahabat berupaya untuk

\footnotetext{
${ }^{3}$ Hamid Mowlana, Global Communication ..., h.114

${ }^{4}$ Hamid Mowlana, Global Communication ..., h.119
} 
melakukannya. Begitu juga terhadap hadis Rasulullah, sebagian Sahabat yang memiliki kemampuan menulis dengan baik banyak menulis hadis, meskipun ada sebagian riwayat yang mengatakan bahwa Sahabat dilarang untuk menulis hadis. ${ }^{5}$

Di dalam al-Qur'an secara eksplisit memberikan penekanan tentang perlunya menulis, seperti yang digambarkan oleh Jalaluddin Rakhmat ketika menafsirkan surat al-Qalam ayat 1 yang mengutip hadis Rasulullah, yaitu: Sesungguhnya yang pertama diciptakan Allah adalah al-Qalam, kemudian Allah menciptakan Nun, yakni tinta. Kemudian ia berkata kepadanya: tulislah. Kata alQalam: Apa yang harus kutulis? Ia berfirman: Tulislah apa yang telah terjadi dan apa yang akan terjadi sampai hari kiamat, baik perbuatan, peninggalan, maupun pemberian. Lalu al-Qalam pun menuliskan apa yang telah dan yang akan terjadi sampai hari kiamat. Itulah maksud firman Allah "Nun, perhatikan al-Qalam dan apa yang dituliskannya". 6

Tradisi tulis-menulis yang pernah terjadi pada zamanRasulullah tidak berkembang pada zaman Sahabat dan Tabi'in. Pada era ini tradisi yang berkembang lebih didominasi oleh tradisi lisan. Tradisi tulis baru mengalami perkembangan signifikan ketika tumbuh industri-industri kertas dan banyaknya penulisan serta penerjemahan yang terjadi pada zaman dinasti Abbasiyah (+ abad ke-VIII dan ke-X). ${ }^{7}$ Tradisi ini pun pada akhirnya mengalami kemunduran dengan

\footnotetext{
${ }^{5}$ Berkenaan dengan aktivitas menulis hadis, ada dua hadis yang berbeda. Satu hadis (riwayat Sa'id al-Hudry) mengatakan untuk melarang menulis hadis dan satu hadis lain (riwayat Abu Hurairah) yang memper-bolehkan untuk menulis hadis. Dua hadis yang bertentangan ini oleh para Ulama dikompromikan, yakni larangan untuk menulis hadis ini diberikan kepada orang-orang yang tidak memiliki kemampuan menulis yang baik, dan larangan terjadi pada awal Islam karena khawatir bercampur antara al-Qur'an dengan al-Hadis.

${ }^{6}$ Jalaluddin Rakhmat, "Di mana Kita Sekarang dan Mau Ke Mana? Peranan Jurnalis Islam”, dalam Rusydi Hamka dan Rafiq (peny.), Islam dan Era Informasi (Jakarta: Pustaka Panjimas, 1989), h. 52

${ }^{7}$ Alamsjah Ratu Perwiranegara, "Prospek Media Massa Islam dalam Era Informasi”, dalam Rusydi Hamka dan Rafiq (Peny.), Islam dan Era Informasi..., h. 42.
} 
hancurnya dinasti-dinasti Islam dan munculnya kejumudan-kejumudan di kalangan umat Islam, terutama setelah abad ke-XI.

Kesadaran mulai bangkit kembali ketika umat Islam berkenalan dengan dunia luar, terutama Barat. Di samping ada motivasi yang tumbuh dari intern umat Islam dan dari ajaran Islam itu sendiri yang banyak mendorong umatnya untuk maju, seperti ajaran yang menjunjung tinggi ilmu pengetahuan (Q.S. alMujadalah: 11), bekerja keras (Q.S. al-Jumu'ah: 10, Q.S. al-Insyirah: 7), memanfaatkan waktu seefektif mungkin (Q.S. Al-Ashr: 1-3), memiliki tanggungjawab dan kepedulian yang tinggi (Q.S. An-Nisa: 58, Q.S. An-Nahl: 90), dan berbagai ajaran lain yang memberikan dukungan positif untuk maju.

Sementara itu, hubungan dengan dunia luar-dalam konteks komunikasi - terjadi pertama kali dengan diperkenalkannya mesin cetak oleh penguasa Mongol pada awal abad ke-13 di wilayah Iran. Umat Islam di wilayah ini diperkenalkan mesin percetakan model Cina yang dipergunakan untuk mencetak uang kertas. ${ }^{8}$ Dan pada abad ke-15 Turki mengenal mesin cetak yang ditemukan oleh Gutenberg yang banyak dimanfaatkan oleh Barat untuk mengembangkan ilmu pengetahuan. ${ }^{9}$ Pengenalan dengan mesin cetak ini membawa perubahan dan perkembangan bagi umat Islam terutama dalam pengembangan ilmu pengetahuan. Banyak buku-buku yang berasal dari Barat dan peninggalan-peninggalan umat Islam (termasuk al-Qur'an) untuk dicetak dan disebarluaskan ke berbagai wilayah Islam. Dari sanalah umat Islam mulai menunjukkan geliatnya untuk bangkit dari tidurnya. Umat Islam mulai menyadari akan ketertinggalannya dengan dunia Barat. Pada awal abad ke-18 umat Islam

\footnotetext{
${ }^{8}$ Bernard Lewis, What Went Wrong? The Clash Between Islam and Modernity in the Middle East (New York: Oxford University Press, 2002), h. 143

${ }^{9}$ Bernard Lewis, What Went Wrong ..., h. 142
} 
mulai bangkit untuk mengadakan pembaharuan-pembaharuan, terutama di bidang pemikiran dan politik.

\section{Peran Dakwah Islam dalam Komunikasi Global}

Berdasarkan paparan di atas jelaslah bahwa secara teologis, Islam tidak menjadi hambatan untuk menjadikan umatnya maju dan berkembang. Bahkan, Islam sangat mendorong umatnya untuk menjadi umat yang terbaik di muka bumi ini (Q.S. Al-Imran: 110). Persoalan mendasarnya terletak pada posisi Islam (negara Islam) dalam komunikasi global di mana hegemoni Barat begitu kokoh dan menjadi pemain utamanya.

Dihadapkan pada persoalan tersebut, ternyata Islam tidak memiliki posisi yang signifikan. Sama halnya dengan negara-negara dunia ketiga pada umumnya. Mereka hanya sebagai negara yang banyak bergantung kepada informasi yang diberikan oleh Barat, khususnya Amerika Serikat. Dalam hal media komunikasi pun, umumnya negara-negara dunia ketiga, termasuk Islam hanya sebagai konsumen yang pemanfaatannya belum maksimal dirasakan oleh seluruh warga negaranya. Apalagi menjadi produsen dalam mencipta-kan media komunikasi, rasanya terlalu jauh untuk diharapkan.

Implikasi yang timbul dari posisi Islam seperti itu, dalam komunikasi global tentunya Islam belum memiliki kekuatan untuk berperan secara signifikan. Kehadiran Islam dalam komunikasi global baru sebatas wacana yang memiliki potensi besar untuk bangkit. Media-media yang banyak dimanfaatkan oleh Iran dalam membangun revolusinya seperti yang diungkapkan oleh Majid Tehranian dalam bukunya Global Communication and World Politics belum memberikan peran dalam percaturan global. Begitu juga, kantor-kantor berita yang ada di negara-negara Arab belum mampu menjadi pemasok berita utama di kalangan masyarakat muslim maupun masyarakat dunia.

Agar lebih meningkatkan perannya dalam komunikasi global, maka umat Islam sudah seharusnya melakukan upaya-upaya sistematis untuk mengejar 
ketertinggalannya. Oleh karena itu, ada beberapa agenda yang dapat ditempuh, yaitu sebagai berikut.

Pertama, era global merupakan moment penting bagi kebangkitan agamaagama. Menurut Naisbitt dan Aburdene, ketika orang-orang diterpa perubahan, kebutuhan akan kepercayaan spiritual semakin menguat. Ilmu dan teknologi tidak mengajarkan kepada kita apa makna hidup. Agamalah yang menjelaskan hal itu. Bagi kebanyakan orang, mencantelkan diri pada suatu budaya dan (atau) agama yang unik adalah suatu keniscayaan. Menganut suatu budaya atau agama tersebut adalah bagian identitas mereka yang membuat mereka tetap eksis di antara bangsa-bangsa dan penganut-penganut agama lain, dan tidak terasing dari lingkungan mereka yang semakin anonim. Manusia memang mempunyai banyak identitas yang berkaitan dengan peran-peran tertentu, namun salah satu identitas terpenting adalah identitas yang berkaitan dengan latar-belakang etnik dan agama mereka, baik disadari atau pun tidak. ${ }^{10}$

Di tengah-tengah momentum yang sangat bagus inilah sudah seharusnya umat Islam memfungsikan agama Islam sebagai sumber vitalitas peradaban. Karena agama, kata Arnold Toynbee, dapat menjadi sumber vitalitas suatu peradaban. Selanjutnya dikatakan "Saya yakin bahwa gaya suatu peradaban adalah perwujudan dari agamanya. Saya amat setuju bahwa agama telah menjadi sumber vitalitas yang telah menyebabkan kehadiran peradaban di dunia dan telah memper-tahankan kehadirannya". Bahkan lebih dari itu, agama merupakan daya ikat spiritual yang telah menyatukan masyarakat yang beradab. "Dua penyakit sosial bawaan bagi peradaban adalah perang dan ketidakadilan sosial. Agama adalah daya pengikat spiritual yang telah menyatukan masyarakat yang beradab untuk suatu kurun waktu, walaupun vitalitasnya digerogoti oleh dua penyakit sosial yang menakutkan itu". ${ }^{11}$

\footnotetext{
${ }^{10}$ Samuel P. Huntington, Benturan Antar Peradaban dan Masa Depan Politik Dunia (Yogyakarta: Penerbit Qalam, 2001), h. 78

${ }^{11}$ Said Tuhuleley, “Agama Pasar: Titik Temu 'Langit' dan 'Bumi'?”, dalam Jurnal Media Inovasi No. 3 TH. X/2001, h. 4
} 
Upaya yang dapat dilakukan yakni menjadikan ajaran Islam sebagai ajaran yang dinamis dan relevan dengan tuntutan zaman, serta diorientasikan kepada kehidupan yang bersifat mondial. Dalam catatan sejarah, di zaman klasik umat Islam dengan pandangan dan orientasi mondial yang positif berhasil menciptakan ilmu pengetahuan yang benar-benar berdimensi universal atau internasional, dengan dukungan dari semua pihak. Hal ini digambarkan oleh Bernard Lewis, seperti yang dikutip oleh Cak Nur:

Pada masa-masa permulaan, banyak pergaulan sosial yang lancar terdapat di antara kaum muslim, Kristen dan Yahudi, sementara menganut agama masing-masing. Mereka mem-bentuk masyarakat yang satu, di mana perkawanan pribadi, kerjasama bisnis, hubungan guru-murid dalam ilmu, dan bentuk-bentuk aktivitas bersama lainnya berjalan normal dan sungguh, umum di mana-mana. Kerjasama budaya ini dibuktikan dalam banyak cara. Misalnya, kita dapatkan kamus-kamus biografi pada dokter yang terkenal. Karya-karya ini, meskipun ditulis oleh orang-orang Muslim, mencakup para dokter Muslim, Kristen dan Yahudi tanpa perbedaan. Dari kumpulan besar biografi itu, bahkan dimungkinkan menyusun semacam proposografi dari profesi kedokteran - untuk melacak garis hidup beberapa ratus dokter praktik di dunia Islam. Dari sumbersumber ini kita mendapatkan gambaran yang jelas tentang adanya usaha bersama. Di rumah-rumah sakit dan di tempat-tempat praktik pribadi, para dokter dari tiga agama itu bekerjasama sebagai rekan atau asisten, saling membaca buku mereka dan saling menerima yang lain sebagai murid. Tidak ada yang menyerupai semacam pemisahan yang biasa didapati di dunia Kristen Barat pada masa itu atau di dunia Islam pada masa kemudian. $^{12}$

Kedua, mengingat hubungan antara Islam dengan media Barat kurang harmonis, maka perlu dilakukan upaya-upaya konkrit. Berikut ini langkahlangkah yang diusulkan oleh Akbar S. Ahmed, yaitu: a) Islam dan Barat masingmasing memposisikan media sebagai pemberi pemahaman dan penyeimbang. Media tidak memberikan keputusan-keputusan dan prasangka-prasangka negatif. Media Barat harus melihat Islam secara objektif, bersikap empathy dan jangan membuat permusuhan; b) Umat Islam perlu ditampilkan di dalam media Barat seperti di dalam film, program diskusi, radio dan sebagainya, agar dapat menangkal kesan dan pandangan negatif terhadap Islam; c) Perlu diadakan konferensi-konferensi dan seminar-seminar bagi masyarakat umum untuk

\footnotetext{
${ }^{12}$ Nurcholish Madjid, Islam Agama Peradaban (Jakarta: Paramadina, 2002), h. 59-60.
} 
menjelaskan Islam di Barat. Sebaliknya, masyarakat Islam juga perlu diberikan informasi tentang Barat; d) Pengetahuan dasar Islam dapat diajarkan di sekolahsekolah Barat agar anak-anak tidak tumbuh dalam kerangka yang salah dan berburuk sangka kepada Islam. Sebaliknya, nilai-nilai Barat, seperti demokrasi dan buku-buku tentang Barat agar diperkenalkan di sekolah-sekolah muslim; e) Problem utama yang banyak menimpa umat Islam perlu diperhatikan seperti di Kosovo, Bosnia, Afganistan dan sebagainya. ${ }^{13}$

Ketiga, umat Islam perlu meningkatkan kemampuannya di bidang teknologi komunikasi, penelitian dan pengembangan ilmu, serta menciptakan kantor-kantor berita agar berita yang disiarkan tidak menimbulkan bias, dan umat Islam tidak dirugikan. Selama ini ketergantungan umat Islam terhadap beritaberita yang bersumber dari Barat tidak bisa dinafikan. Akibatnya Islam seringkali menjadi sasaran empuk untuk konsumsi media Barat dan menjadi pihak yang seringkali tertuduh.

Keempat, institusi-institusi yang telah terbentuk di kalangan umat Islam, seperti OKI, Liga Arab, WAMY dan sebagainya, dapat memainkan perannya dalam percaturan global karena dalam percaturan global, peran utama tidak lagi ada di tangan negara, melainkan pada aktor-aktor non-negara. Oleh karena itu, pada era global ini merupakan kesempatan yang baik bagi institusi-institusi Islam untuk menun-jukkan kiprahnya dalam masyarakat luas.

Kelima, kerjasama antarnegara-negara Islam perlu ditingkatkan, terutama di bidang ekonomi dan sosial-budaya. Kerjasama regional dan memiliki kesamaan kultur atau agama dapat menjadikan kekuatan inti pada era global. Negara-negara Islam dengan kesamaan ideologi atau agama dapat menjadi kekuatan di masa depan apabila mau melakukan kerjasama dengan baik. Persoalannya tinggal seberapa besar kemauan itu untuk direalisir dalam kehidupan nyata.

\footnotetext{
${ }^{13}$ Akbar S. Ahmed, Islam Today: A Short Introduction to The Muslim World (London and New York: I.B. Tauris Publishers, 2001), hal. 235-236
} 


\section{Kesimpulan}

Islam sebagai agama rahmatan lil 'alamin memiliki nilai-nilai dan tradisi berkomunikasi. Dalam perjalanan sejarahnya, nilai-nilai dan tradisi berkomunikasi yang telah dibangun pondasi-pondasinya pada zaman Rasulullah, mengalami pasang-surut sesuai dengan dinamika yang berkembang dalam perjalanan sejarah umat Islam.

Dalam era global posisi dan peran Islam dalam komunikasi global belum menunjukkan peran yang signifikan. Hegemoni Barat masih begitu kuat dalam menguasai komunikasi global. Semua lini-bisa dikatakan-tidak terlepas dari intervensi Barat. Pada posisi demikian, Islam tidak harus berpangku tangan sambil merenungi nasibnya, melainkan perlu upaya-upaya yang sistematis agar dapat memainkan perannya di dalam komunikasi global.

Upaya-upaya yang harus dilakukan adalah: Pertama, menjadikan ajaran Islam sebagai sumber vitalitas peradaban; Kedua, membangun kerja sama yang harmonis antara Islam dengan Barat, terutama medianya; Ketiga, meningkatkan kemampuan umat Islam dalam penguasaan ilmu dan teknologi, khususnya komunikasi serta membangun kantor-kantor berita dunia; Keempat, institusiinstitusi Islam dapat memainkan perannya dalam percaturan global; Kelima, kerjasama antarnegara Islam perlu ditingkatkan.

\section{Daftar Pustaka}

Akbar S. Ahmed, Islam Today: A Short Introduction to The Muslim World (London and New York: I.B. Tauris Publishers, 2001).

Alamsjah Ratu Perwiranegara, "Prospek Media Massa Islam dalam Era Informasi”, dalam Rusydi Hamka dan Rafiq (Peny).

Bernard Lewis, What Went Wrong? The Clash Between Islam and Modernity in the Middle East (New York: Oxford University Press, 2002).

Deddy Mulyana, Nuansa-Nuansa Komunikasi Meneropong Politik dan Budaya Komunikasi Masyarakat Kontemporer (Bandung: Remaja Rosdakarya, 1999). 
Hamid Mowlana, Global Communication In Transition The End of Diversity? (California: Sage Publications, Inc, 1996).

Jalaluddin Rakhmat, "Di mana Kita Sekarang dan Mau Ke Mana? Peranan Jurnalis Islam", dalam Rusydi Hamka dan Rafiq (peny.), Islam dan Era Informasi (Jakarta: Pustaka Panjimas, 1989).

Nurcholish Madjid, Islam Agama Peradaban (Jakarta: Paramadina, 2002).

Said Tuhuleley, “Agama Pasar: Titik Temu 'Langit' dan 'Bumi'?”, dalam Jurnal Media Inovasi No. 3 TH. X/ 2001.

Samuel P. Huntington, Benturan Antar Peradaban dan Masa Depan Politik Dunia (Yogyakarta: Penerbit Qalam, 2001). 